\title{
Appraisal of Deforestation in Murree through Open Source Satellite Imagery
}

\section{Tabasam Jamal', Shoaib Naseer², Syed Shehzad Hassan²*, Hafsa Batool'2, Rashid Mahmood2, Attia Naz ${ }^{2}$, Atif Butt ${ }^{2}$, Usman Tanver ${ }^{2}$, Imran Saddique Kaukab², Sana Alvi², Javed Ahmad ${ }^{2}$, Azeem Akhtar ${ }^{2}$, Arshid Javed ${ }^{2}$, A. Ali ${ }^{2}$}

${ }^{1}$ Department of Geography, University of the Punjab, New Campus Lahore, Punjab, Pakistan

${ }^{2}$ Remote Sensing Group, Department of Space Science, University of the Punjab, Lahore, Pakistan

Email: *smhn72@gmail.com

How to cite this paper: Jamal, T., Naseer, S., Hassan, S.S., Batool, H., Mahmood, R., Naz, A., Butt, A., Tanver, U., Kaukab, I.S., Alvi, S., Ahmad, J., Akhtar, A., Javed, A. and Ali, A. (2018) Appraisal of Deforestation in Murree through Open Source Satellite Imagery. Advances in Remote Sensing, 7, 61-70.

https://doi.org/10.4236/ars.2018.72005

Received: December 20, 2017

Accepted: May 13, 2018

Published: May 16, 2018

Copyright $(9) 2018$ by authors and Scientific Research Publishing Inc. This work is licensed under the Creative Commons Attribution-NonCommercial International License (CC BY-NC 4.0). http://creativecommons.org/licenses/by-nc/4.0/ (c) (i) \& Open Access

\begin{abstract}
Forests are the main source of income for humans and shelter for many rare in habitants. Forests act as carbon sink and help to reduce the effect of natural hazards like floods. The timber is among the main products of forests used for precious furniture. Forest must cover one third of the part of any country but in Pakistan, it covers less than $4 \%$. If the deforestation continues with the same ratio, there will be a drastic change in the upcoming years. The main objective of the study is to determine deforestation rates in Murree for the years 1999-2015 through open source Landsat 7, 8 imageries. The areas with high deforestation rates are also delineated. Supervised classification is used to delineate the area under buildup, vegetation and water that was $83.85 \mathrm{~km}^{2}$, $760.63 \mathrm{~km}^{2}$ and $1.18 \mathrm{~km}^{2}$ respectively in 1999 . Built up area increased up to $20 \%$ and forests declined by $23 \%$ in 2015 as compared to 1999 . Remote sensing and GIS tools helped to investigate the deforestation rates with high accuracy.
\end{abstract}

\section{Keywords}

Landsat 7, Landsat 8, Supervised Classification, Deforestation, Vegetation Index

\section{Introduction}

A forest is a large area which is dominated by trees. Forest can be defined many ways like on the basis of its height, land use ecological function, density and legal standing. The word forest comes from Middle English which mean "vast ex- 
panse covered by trees". The trees are covering one third part of land area. The trees have gross primary productivity is $75 \%$ while earth plant biomass is $80 \%$. Tropical Rainforest found between $23.5^{\circ} \mathrm{N}$ and $23.5^{\circ} \mathrm{S}$. The temperature remains between $20^{\circ} \mathrm{C}$ to $25^{\circ} \mathrm{C}$. It received 100 inches of rain per year. The decomposition happens at a very fast rate due to moist air and warm temperature. Temperate Deciduous forest is located in China, East side of Canada and United States, Japan, some parts of Russia and western part of Europe. There are four seasons in these types of forest. It receives around 30 to 60 inches of rain per year. Temperate Coniferous forest can be found in the mild winter in coastal areas and mountains and heavy rainfall and the places like southwest of South America, New Zealand, Ireland, Scotland, south of Japan, Pacific North-western United States and Canada and Norway. The temperature fluctuates little all over the year and it receive large amount of rain i.e. 50 to 200 inches per year in this area. So, its mean it has very moist and long seasons. Boreal Forest is located at latitude of $50^{\circ} \mathrm{N}$ and $60^{\circ} \mathrm{N}$. Examples of areas are Denmark, Norway, Canada, North of Asia and Siberia. It has only two seasons i.e. short summers and long winters. Long winters mean that this forest receives 15 to 40 inches of rain per year and most of the form is ice. Due to long winters, the decomposition rate is slow. The types exist in Pakistan are Littoral and Swap forests, Tropical dry deciduous forests, Tropical thorn forests, Sub-tropical broad-leaved evergreen forests, Sub-tropical pine forests, Himalayan moist temperate forests, Himalayan dry temperate forests, Sub-alpine forests and Alpine scrub. The satellite imagery is a method for taking the information and identification of the land cover by using a specific resolution of the Remote sensing data. The remote sensing data provides lot of information about the urbanization and industrialization in this era of technology. The remote sensing and GIS can identify the particular areas where the resources are decreasing or not using. The data of the satellite imagery can also identify the time duration of this depleting resources. Different types of resolution imageries can be used but Landsat imageries are preferred due to free and medium resolution imagery [1] [2]. The remote sensing techniques used for the recognition and observing the difference in forest area over two or more-time periods which is usually caused by the human actions and environmental conditions. To estimate and validate environmental changes arise from the management's inclusion in forest can be found by using the tools of remote sensing and GIS. The quantitative knowledge about the change in land cove can compare different ecosystem services within and across different countries [3] [4]. The data of remote sensing provide a better and quick process for the identification and explain the various species of forest rather than the traditional ways of ground surveys which are very time consuming. Upon the local or regional demands, anyone can use particular scales and resolution. Various air photo data, hyperspectral and multispectral can be used to identify and interpret the different species [5]. Lambin and Strahler (1994) [6] had discussed the factors which influence on the land cover change. These factors include soil erosion, increase 
in cultivation area, and change in climatic conditions over a long period of time, effects of greenhouse, deforestation and inter-annual climate variability. Although the resources of forest in Pakistan is present in less amount but it plays a major role to the economy of Pakistan. The forest is the source of production of water, conservation of soil and flow of the water. The forest provides different function like protective, socio-cultural, regulative and productive. Due to unaware of benefits from the products of tangible forest leads to disturb the ecological balance [7]. The source of the income of the rural mountainous areas in Khyber Pakhtunkhwa mostly comes from the forest resources and trees. The forest helps in various ways like timber used for houses, fodder for livestock and mostly the wood used as a fuel for cooking and heating. The diverse non-timber-forest is also the source of income for these people [8]. The source of income in the mountainous areas of Khyber Pakhtunkhwa comes from farming. They cut the forest to increase the area of cultivation [9] [10]. The gradual decrease in the forest is an environmental concern for Pakistan. Approximately, thirty-nine thousand hectares of forest disappear every year. According to Food and Agricultural organization, the rate for the deforestation is $1.5 \%$ per year [11]. According to Geiser \& Steimann (2004) [12], the people lives around the forest are the major cause for the deforestation. Increase in population, merciless cutting of forest, scarcity, lack of awareness, removal of dense growth of shrubs and other plants and overgrazing are the major reason of deforestation [13]. According to Mahmood (2003) [14], the major cause of deforestation is increase in the area of cultivation land, expansion of urban areas, fuel food, over gazing, timber mafia and road expansion or construction. Many authors blame the inefficiency and unmanageable of the departments of the forest for the deforestation. This department focuses on development projects but unware of impacts on environments [15] [16]. The extensive developments for the social and economic in the plain areas require the luxury life style like furniture and households, expansion of roads, motorways and ring roads. The hilly region provides timber for this development projects which is also a source of income in that area [17]. The main reason of the deforestation is the increase in the population and its growth. To overcome this problem, deforestation is the solution in the developing countries. Angelsen and Kaimowitz, (2001) [18] indicated the traditional use of technology in the agricultural lands around the forest area. The orthodox methods with unplanned-selective logging play a major role in deforestation [19]. The role of private institutions and public plays an important role to control the deforestation in Murree and its outskirts. There must be an environment policy whose responsibility is to control and look up the amount of deforestation. Unfortunately, there is no management in Murree to look after this illegal cutting of forest. Thus, the institute is responsible for these environmental problems [20] [21] [22]. The governance failure is the cause of the underdeveloped of the third world countries. There is no proper statement of the governance failure can be found. Krueger (1990) [23] defines as the failure to act which causes the 
suboptimal situations. The institutional failure is also the major cause of deforestation. The failures of the market and weakness in governance are the major reasons among the deforestation [24].

\section{Objectives of Study}

The basic purpose of the study is to evaluate the amount of deforestation in Murree, Pakistan. We selected this topic because the overall forest cover is less than $4 \%$ and it is gradually decreasing which is an alarming situation. In order to run the factories and household necessities we are burning more forest day by day. Recently large amount of forest cut down to build Islamabad Murree Expressway which provide better route to Murree. More development project starts around this road which increases the deforestation. Our aim is to determine the amount and cause of deforestation in the Murree region in the span of 16 years i.e. from 1999 to year 2015 .

\section{Study Area}

Murree is subdivision of Rawalpindi and situated at $33.9078^{\circ} \mathrm{N}$ and $73.3915^{\circ} \mathrm{E}$ and at an altitude of approximately 7500 feet mapped in Figure 1. It is connected with the district of Haripur and Abbottabad Khyber Pakhtunkhwa towards north and western side, at the eastern side Jhelum River, while on the

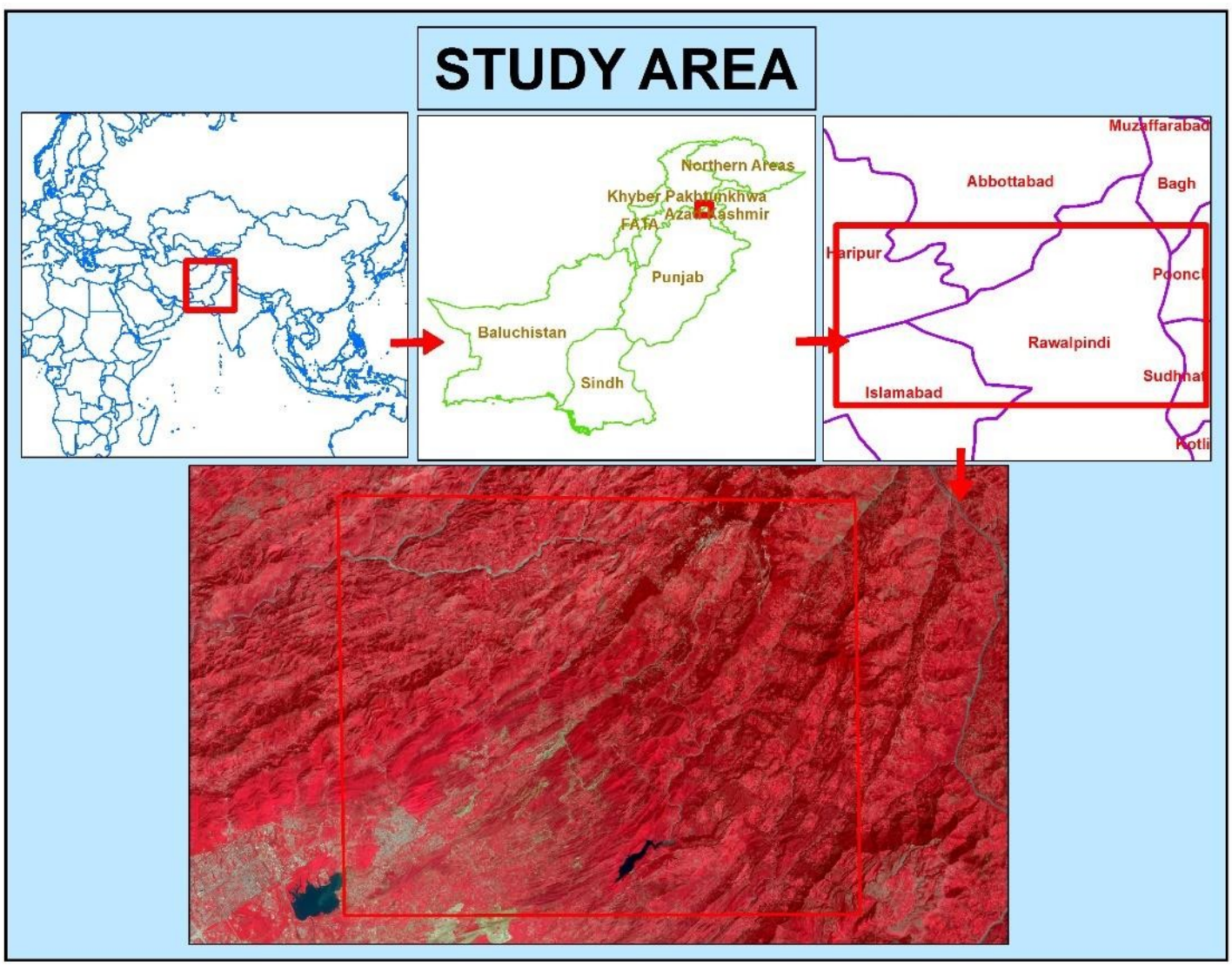

Figure 1. Location of study area. 
southern side of Murree Rawalpindi's district Kotli Satian is located. Murree is also known as Queen of Hills. Murree is famous for its mountainous region which attracts the local and foreigners from all around the world. The season of summer is much pleasant while the mountains are covered with the blanket of snow in the winter season.

\section{Materials and Methods}

We acquired the data from the http://glovis.usgs.gov/. Two imageries of Landsat are used to compare the deforestation in Murree and its outskirts. We use the two imageries i.e. Landsat 7 (15-8-1999) and Landsat 8 (04-09-2015). The main reason is the SLC-off data which shows data gaps after 31 May 2003. Almost $22 \%$ data is lost due to this failure. Although there is some estimation methods to fix this problem. But we prefer to use the data when SLC is in working mode. Secondly, the process of deforestation is slow, so if we have to detect the change we must have time lap. It's the main reason, we give the 16-year gap between the two imageries. Thirdly, the data must be of similar months of the two imageries. The seasonal variation plays a part if the data comprises of different months. For example, the data of August and November can be compared but the result varies due to seasonal change. We compare the data in which the season is same and from the above-mentioned date, we can see the difference is only 19 days. The downloaded imagery has individual bands in a folder. We cannot apply any type of band combination to explore the features. For this reason, the layer has to stack in a proper order so we can verify the features on the bases of their spectral reflectance. The distortion between image actual coordinates and ideal coordinates termed as geometric distortion. The errors occur due to the geometry of the sensor and shape of the object from the altitude of the sensor. We can adjust these errors using appropriate algorithms. The technique of image enhancement is used to make easy visual interpretation so that we can easily understand about the feature of the land cover. We use the vegetation indices to enhance the vegetation part in the imagery. While the other indices of build-up area are also used. We can differentiate between build up and vegetation areas in a more convenient way. The Landsat imageries cover the larger area of $175 \mathrm{~km}$ * $185 \mathrm{~km}$. It's necessary to subset our Area of Interest because processing time will be less as compared to the full imagery. The process to transform multispectral image into user defined thematic information classes. Firstly, identify training areas of uniform class land cover by drawing the polygons by using the annotation tool. We identify the training areas through the spectral signatures. We give three major classes i.e. vegetation, water and build up. After running the process of supervised classification, we obtained the thematic map. After classification, the raster becomes a thematic map which shows different classes based on our training area. Different types of polygon are made on the basis of classes given i.e. vegetation, build up, water and Islamabad Murree Express Way. The three mentioned classified polygons are verified with the help of ground truthing. The 
ground truthing helps to rectify boundaries of build-up, vegetative and water area. Finally, the polygons are merged on the basis of land cover and calculate the areas for further analysis.

\section{Results \& Discussions}

In this research, supervised classification is applied on the satellite imagery of Landsat 7 and Landsat 8 . We made different types of categories on the basis of spectral signature. The categories are build up, vegetation, water and Islamabad Murree expressway.

As from the statistics, we can see there is sharp increase in built up area which increase from $73.85 \mathrm{~km}^{2}$ in 1999 mapped in Figure 2 to $243.09 \mathrm{~km}^{2}$ in 2015 in Figure 3. This drastic change effects are mentioned in Table 1 for the both water and vegetation area. The water resources are also depleting and the green part of Murree is also losing its traditional beauty. The decrease in forest not only effects on animals but also effects both on human and environment.

Figure 4 represents the spatio-temporal change occurs over a period of time. Since the Islamabad Murree Express Way is built, the build-up is significantly increasing. The increase in residential areas is causing many impacts on the inhabitants. The major impacts are the global warming and pollution which in result affecting the tourism. The increase in built up also shows there is also increase in restaurants and hotels which is affecting the beauty and hygienic air of the Murree.

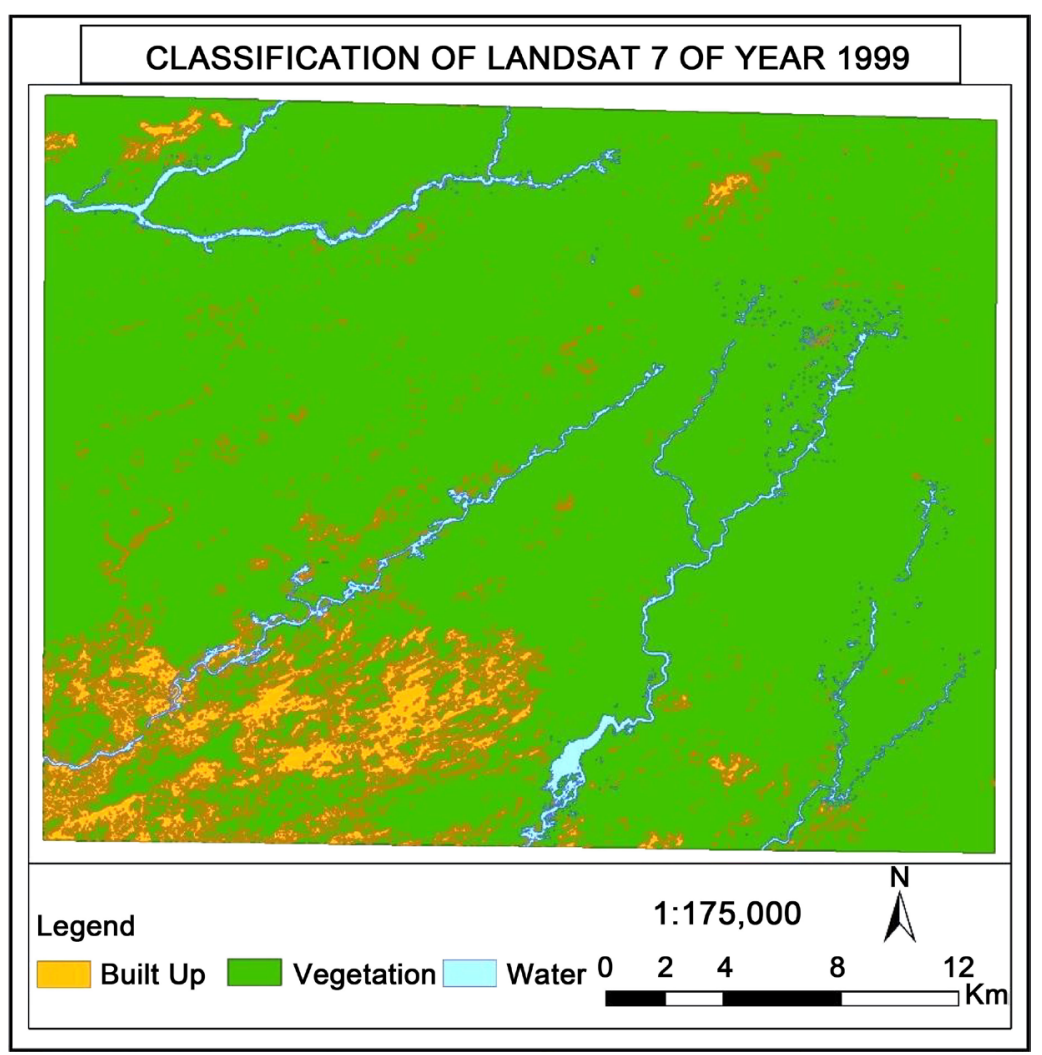

Figure 2. Supervised classification map of 1999. 


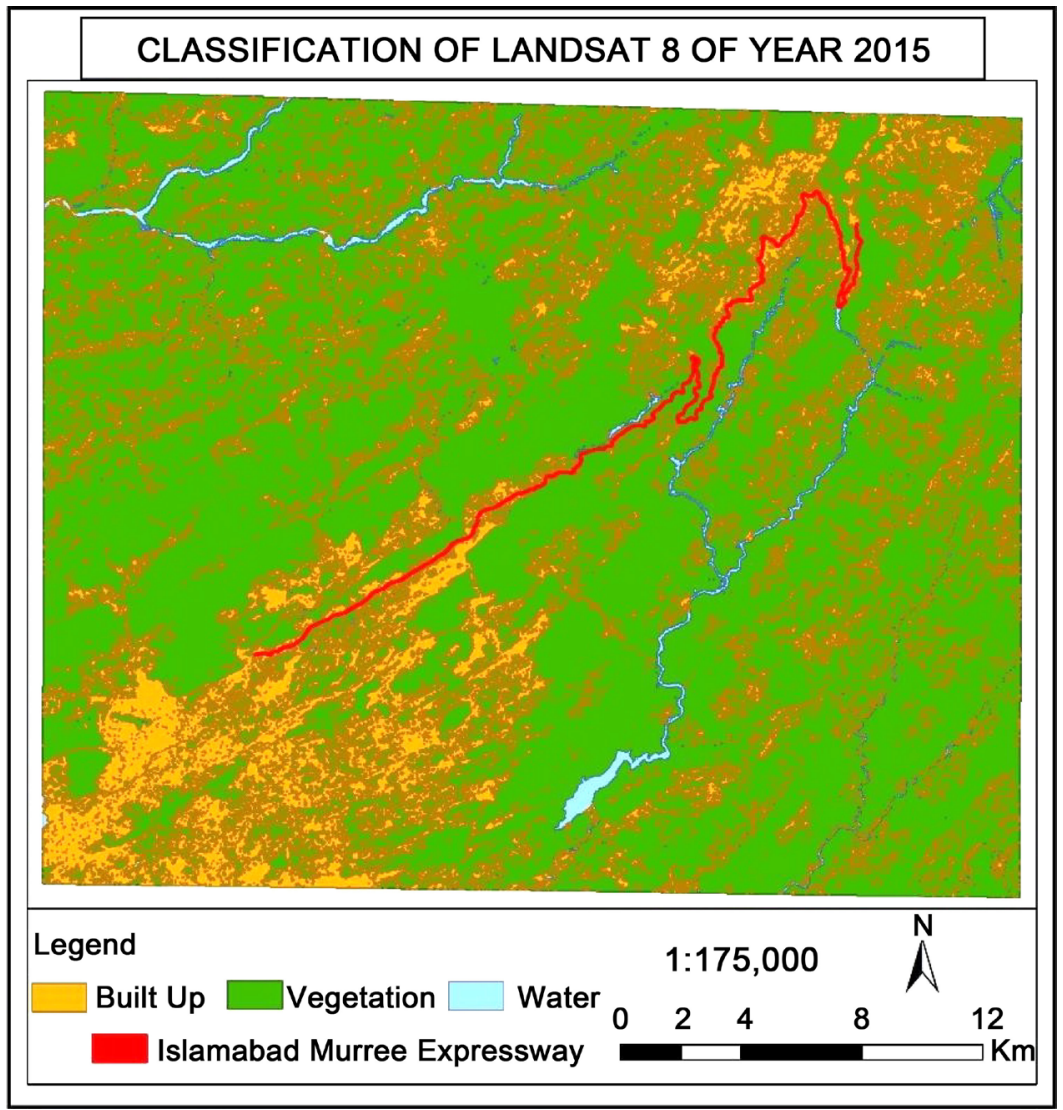

Figure 3. Supervised classification map of 2015.

Table 1. Spatio-temporal comparison vegetation degradation.

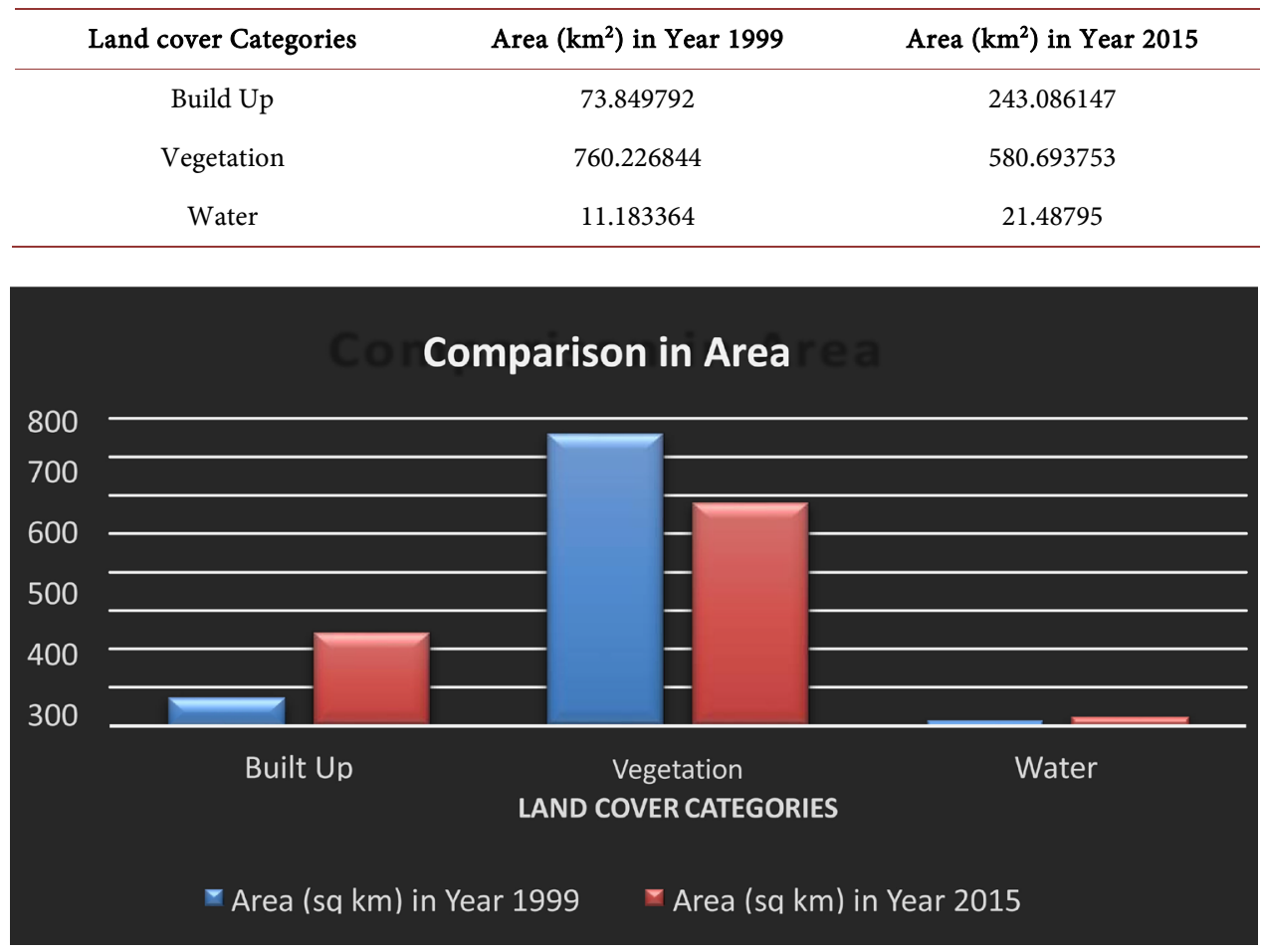

Figure 4. Comparison of area (sq $\mathrm{km}$ ) of Landsat 7 and Landsat 8. 


\section{Discussion}

Approximately $15 \%$ to $30 \%$ of the volume of the wood is traded as illegal around the world. The mafia is far more dangerous than the investment in off shore companies. The forest also acts as Green carbon because it stores and bind carbon dioxide. According to Pakistan government the forest covers $4.1 \%$ of the country. The deforestation rate is $2.5 \%$ which is an alarming situation. Different companies are responsible for the deforestation in the area around Islamabad Murree Express Way. These companies illegally transport the wood of the trees which cause the loss of many species. The main problem which helps timber mafia is that the forestry department has no record of the total number of trees. Secondly, some persons also help this mafia to smuggle the wood to other cities. Murree is popular for the royal trees which sells at a very expensive rate. If it is difficult to smuggle the woods, they convert it into the furniture.

\section{Social Impacts of Deforestation}

Murree is located on the northern side of Pakistan and its location is associated with the Indian border. The soldiers and their armoury use forest as a safe place to hide from enemy. But the gradual deforestation causes a threat to their life. It is nearly impossible to hide from the enemy with less amount of forest. The deforestation is also hurting the economy. The global GDP could reduce to 7\% in 2050 due to deforestation impacts on forests, rivers and marine life. Approximately 30 lakhs people are depending on woods for heating and cooking, so cutting of forest effects on those peoples. The long-term income and biological productivity also effects when the forests cut down to make them agricultural land. The deforestation also effects on the tourists which visits to enjoy the beauty of the nature. According to Food and Agricultural Organization the forest plays an important role for the developing countries. According to National Geographic $70 \%$ of the plants and animals are losing their habitats due to cutting of forest. The nutrients of any forest come from the decaying plant and animals matters on the forest floor. The rare species found in the forest could extinct due to deforestation from the Timber Mafia. The canopy of the tress acts as a shelter for the plants and animals. The cutting of forest provides temperature variations which is fatal for the inhabitants. The loss of any specie means loss of information of that particular specie. This information may help in the field of medicine and agriculture. The same case is happening in Murree which causes loss of rare species of plants and animals or force them to migrate to other places. Murree is one of the most popular places in Pakistan. During vacations the people moved here to enjoy the beauty of the nature. But the regular deforestation extinguishing the beauty which causes fewer visitors is to come. The trees bind the soil with the help of their roots. If there is heavy rain or storm the soil will washed away but in case of trees the possibility is very less. The deforestation in Murree causes the soil erosion which also effects in the growth of the plants. To increase the area of agriculture land to plant palm oil, coffee, wheat, cotton and soybean by 
cutting the natural forest causes the soil erosion. Because these types of plants cannot hold the soil as compare to the strength of natural vegetation. In the recent 150 years we lost half of the topsoil. It also influences on the nutrient degradation, loss of soil structure, soil salinity and compaction. The deforestation also causes the flood because the trees stop the flow of sediments. In 1947, when Pakistan takes independence, riverine forest had been present at the banks of Indus River. This forest use as an anchor and absorbs the ferocity of the flood water. It means that the forest is the first line defines against flood waters. During rainfall, the rainwater gets trapped in branches, leaves and roots which help to slow the flow of floodwater. We are inviting more floods due to the deforestation process. Life suffers badly from the deforestation in many ways. The deforestation is responsible for $20 \%$ of the world's greenhouse gas emissions. Indirectly its effects enhance by the less absorption of carbon dioxide and also release less amount of oxygen. The greenhouse effect is responsible for the increase in temperature. Due to the soil erosion, the lake or water resources polluted by the sediments which will affect the inhabitant. If the area of build-up increases it will also affect the groundwater. The main reason is seepage of water in the ground. It also effects on the water cycle because the trees control the level of the water in the atmosphere. Less number of tress means less absorption of water from the leaves. It results in less rainfall and also it dries the soil. The dry soil means the inability to grow different types of growth. Major part of the source of the income of Murree comes from the tourist which also relates with GDP of the country. The beauty of nature also reduces with the deforestation which causes fewer tourists to visit. The main reason of this decrease is the unproductive land and loss of rare species. The GDP of country will affect due to less number of tourists. So, we will have to save the forest of Murree to increase the tourist.

\section{References}

[1] Yang, X. (2002) Satellite Monitoring of Urban Spatial Growth in the Atlanta Metropolitan Area. Photogrammetric Engineering \& Remote Sensing, 68, 725-734.

[2] Francisco, J. and Tapiador, J.L. (2003) Land Use Mapping Methodology Using Remote Sensing for the Regional Planning Directives in Segovia, Spain. Landscape and Urban Planning, 103-115. https://doi.org/10.1016/S0169-2046(02)00126-3

[3] Kreuter, U.P., Harris, H.G., Matlock, M.D. and Lacey, R.E. (2001) Change in Ecosystem Service Values in the San Antonio Area, Texas. Ecological Economics, 39, 333-346. https://doi.org/10.1016/S0921-8009(01)00250-6

[4] Zhang, S.Q., Zhang, S.K., Zhang, J.Y., et al. (2000) A Study on Wetland Classification Model of Remote Sensing in the Sangjiang Plain. Chinese Geographical Science, 10, 68-73. https://doi.org/10.1007/s11769-000-0038-1

[5] Canada Centre for Remote Sensing Tutorials (2008) Fundamentals of Remote Sensing Introduction Date Modified.

[6] Implications for Policy and Human Resource's Development in the Hindukush-Himalayas p. 79. Volume VI Pakistan. International Centre for Integrated Mountain Development (ICIMOD), Kathmandu.

[7] Lambin, E.F. and Strahler, A. (1994) Remotely-Sensed Indicators of Land-Cover 
Change for Multitemporal Change-Vector Analysis. International Journal of Remote Sensing, 15, 2099-2119. https://doi.org/10.1080/01431169408954230

[8] Khan, R.A. and Mehmood, R.T. (2003) Potential and Prospects of Mountain Forests. Mountains of Pakistan: Protection, Potential and Prospects, 58-72.

[9] Khan, S.R. and Naqvi, A.A. (2000) The Environment-Poverty Nexus: An Institutional Analysis. United Nations Development Programme.

[10] Hussain, S.S. (2003) Mountain Ecosystems: Emerging Challenges and Opportunities for Agriculture in Northern Pakistan. Mountains of Pakistan: Protection, Potential and Prospects, 180-191.

[11] Steimann, B. (2004) Livelihood Strategies in North West Pakistan. IP-6 Working Paper No. 5, Development Study Group, University of Zurich, Switzerland, 92.

[12] FAO (2005) State of the World's Forests-2005. Food and Agricultural Organization (FAO), Rome, Italy.

[13] Geiser, U. and Steimann, B. (2004) State Actors' Livelihoods, Acts of Translation and Forest Sector Reforms in Northwest Pakistan. Contemporary South Asia, 13, 437-448. https://doi.org/10.1080/09584930500070670

[14] Mehmood, I. (2003) Deforestation in NWFP. National Institute for Public Administration, Karachi (Pakistan). International Journal of Forest and Biology, 8, 75-101.

[15] Iqbal, M. (2000) Institutional Changes in North West Frontier Province, Forest Department, Pakistan. In: Bhatia, A., Ed., Participatory Forest Management. Implications for Policy and Human Resource's Development in the Hindukush-Himalayas, Vol. VI, Pakistan. International Center for Integrated Mountain Development (ICIMOD), Kathmandu, 79.

[16] Shahbaz, B., Ali, T. and Suleri, A. (2006) A Critical Analysis of Forest Policies of Pakistan: Implications for Sustainable Livelihood. Mitigation and Adaption Strategies of Global Change. Springer Link, The Netherlands.

[17] Ali, J., Benjaminsen, T.A., Hammad, A.A. and Dick, Ø.B. (2005) The Road to Deforestation: An Assessment of Forest Loss and Its Causes in Basho Valley, Northern Pakistan. Global Environmental Change, 15, 370-380. https://doi.org/10.1016/j.gloenvcha.2005.06.004

[18] Angelsen, A. and Kaimowitz, D. (2001) Agriculture Technologies and Tropical Deforestation. CABI, Wallingford, 422 p. https://doi.org/10.1079/9780851994512.0000

[19] Groten, S.M.E., Immerzeel, W. and Leeuwen, L.V. (1999) Monitoring of Crops, Rangelands and Food Security at National Level. ITC-FAO, Rome.

[20] Aron, J. (2000) Growth and Institutions: A Review of the Evidence. The World Bank Research Observer, 15, 99-135. https://doi.org/10.1093/wbro/15.1.99

[21] Harris, J., Hunter, J. and Lewis, C.M., Eds. (1995) The New Institutional Economics and Third World Development. Routledge, London.

[22] North, D.C. (1990) Institutions, Institutional Change and Economic Performance. Cambridge University Press, New York. https://doi.org/10.1017/CBO9780511808678

[23] Krueger, A.O. (1990) Government Failures in Development. Journal of Economic Perspectives, 4, 9-23. https://doi.org/10.1257/jep.4.3.9

[24] Contreras-Hermosilla, A. (2000) The Underlying Causes of Forest Decline. CIFOR Occasional Paper No. 30, Centre for International Forestry Research, Bogor, Indonesia. 